Review

\title{
Developmental Programming of Fetal Skeletal Muscle and Adipose Tissue Development
}

\author{
Xu Yan', Mei-Jun Zhu1, Michael V. Dodson², and Min Du'1,2凶 \\ 1. Department of Animal Sciences, University of Wyoming, Laramie, WY 82071 \\ 2. Department of Animal Sciences, Washington State University, Pullman, WA 99164
}

Corresponding author: Department of Animal Sciences, Washington State University, Pullman, WA 99164; Phone: 509-335-2744; Fax: 509-335-1082; E-mail: min.du@wsu.edu.

(C) Ivyspring International Publisher. This is an open-access article distributed under the terms of the Creative Commons License (http://creativecommons.org/ licenses/by-nc-nd/3.0/). Reproduction is permitted for personal, noncommercial use, provided that the article is in whole, unmodified, and properly cited.

Published: 2013.11 .08

\begin{abstract}
All important developmental milestones are accomplished during the fetal stage, and nutrient fluctuation during this stage produces lasting effects on offspring health, so called fetal programming or developmental programming. The fetal stage is critical for skeletal muscle development, as well as adipose and connective tissue development. Maternal under-nutrition at this stage affects the proliferation of myogenic precursor cells and reduces the number of muscle fibers formed. Maternal over-nutrition results in impaired myogenesis and elevated adipogenesis. Because myocytes, adipocytes and fibrocytes are all derived from mesenchymal stem cells, molecular events which regulate the commitment of stem cells to different lineages directly impact fetal muscle and adipose tissue development. Recent studies indicate that microRNA is intensively involved in myogenic and adipogenic differentiation from mesenchymal stem cells, and epigenetic changes such as DNA methylation are expected to alter cell lineage commitment during fetal muscle and adipose tissue development.
\end{abstract}

Key words: Maternal nutrition, fetal muscle development

\section{Introduction}

Obesity has become an epidemic. In the United States, more than one third of the population age 20 or older are obese (2007-2008) [1]. Data from Centers for Disease Control and Prevention shows that the overall obesity rate in 1989 was less than $15 \%$, ten year later in 1999 , the obesity rate was about $25 \%$, and in 2009 it was $34 \%$, showing that obesity is increasing rapidly in recent decades. Associated with the overall trend of increased obesity, obesity in non-pregnant women of child bearing age (between 20 to 39 yr old) is also becoming more and more prevalent, and has reached more than $30 \%$ [1]. Furthermore, nearly $17 \%$ of children and teenagers from 2-19 yr old were found to be obese [2]. Maternal obesity affects fetal development $[3,4]$, which is associated with obesity in offspring [5, $6]$.

In addition to maternal obesity, maternal nutrient deficiency results in insufficient nutrient supply to the fetus, negatively affecting fetal development [7]. Fetal nutrient deficiency results from many conditions in pregnancy, including maternal malnutrition, reduced placenta efficiency, adolescence pregnancy, and closely spaced pregnancy. Compared to brain and heart, skeletal muscle and fat have a lower priority for nutrition repartitioning, which makes the development of skeletal muscle and adipose tissue es- 
pecially vulnerable to nutritional deficiency [8]. In this review, we focus our discussion on the effect of maternal nutrition on fetal skeletal muscle and adipose tissue development, and how fetal developmental programming might regulate the differentiation of myocytes, adipocytes and fibrocytes, as well as their impacts on postnatal body composition.

\section{Skeletal Muscle, Adipose and Connective Tissue Development}

\section{Skeletal muscle development}

Muscle fibers or myofibers are the structural units of skeletal muscle [9]. The formation of new muscle fibers is termed myogenesis, a differentiation process where multipotent stem cells are converted into committed muscle cells. In livestock, all muscle fibers are formed during the prenatal stage. Consequently, understanding the prenatal development of skeletal muscle is important, because events occurring at this stage have dramatic impact on postnatal development and growth (Dauncey and Harrison 1996).

Prenatal myogenesis can be divided into primary myogenesis and secondary myogenesis. Primary myogenesis mainly occurs during the embryonic stage, when primary muscle fibers arise; secondary myogenesis occurs during the fetal stage, and leads to the formation of secondary muscle fibers. Only a small number of primary muscle fibers develop during the embryonic period, which will serve as templates for the formation of secondary muscle fibers during the fetal stage. Both primary and secondary muscle fibers are derived from a pool of cells termed mesenchymal stem cells [10], which can be committed to a myogenic linage as well as other cell types such as adipocytes and chondrocytes. However, the committed cells, termed myogenic progenitor cells, are not yet muscle cells. Prenatal myogenesis is under the control of a panel of regulatory proteins, including Wingless and Int (Wnt), paired box gene (Pax) 3 and Pax 7 [11, 12]. Wnt signaling is very important for activating myogenesis [13]. The expression of Pax 3 and Pax 7 in mesechymal stem cells induces the expression of myogenic regulatory factors (MRFs) [10], which leads to myogenic differentiation [14]. Currently identified MRFs include myogenin, MRF-4, Myo-D and Myf-5 [15]. MRF-4 is mainly expressed at the very early stage of myogenesis, followed by the expression of MyoD and Myf-5, which converts precursor cells into myoblasts [15]. Myogenin is necessary for the fusion of myoblasts into myotubes [16] and is expressed later and maintained throughout the fetal stage. MRF-4 is also expressed later and becomes the dominant MRF in postnatal muscle. MyoD and
Myf-5 function compensatively to induce the differentiation of multipotent myogenic precursor cells into myoblasts [17].

Both myogenic precursor cells and myoblasts proliferate to increase their numbers. When there are pertinent environmental signals, myoblasts align with each other, fuse and differentiate into immature muscle fibers known as myotubes [18]. The exact process regulating myoblast fusion is not well understood. Because myogenic cells are derived from myogenic progenitor cells, increasing the proliferation of progenitor cells increases the number of myogenic cells which will form more primary myofibers. Due to the fact that only a very limited number of primary myofibers are formed during the embryonic stage, the impact of primary myogenesis on subsequent size and number of muscle fibers formed in the offspring is relatively minor [19].

Secondary myogenesis forms the majority of muscle fibers. Therefore, the fetal stage, when secondary myogenesis is ongoing, is critical for skeletal muscle development $[18,20]$. Since the number of muscle fibers formed during the fetal stage is dependent on the number of available myogenic progenitor cells and their proliferation is highly sensitive to nutrients, maternal nutrition dramatically affects skeletal muscle development during this stage [7, 21-23].

The postnatal skeletal muscle development is mainly due to the increase in muscle fiber size, with no net formation of new muscle fibers [24]. New muscle fibers generated during the adult stage are only to replace injured muscle fibers [19].

The increase in muscle fiber size at the adult stage mainly relies on muscle satellite cells. Satellite cells are a population of postnatal myogenic stem cells located between the sarcolemma and basal lamina [25]. Satellite cells are dormant mononucleated cells, which are at the G0 phase of the cell cycle. Although the specific population dynamics of the cells are unknown, numerous subpopulations of these cells are found in skeletal muscle. After activation by various environmental stimuli related to growth, satellite cells undergo asymmetric proliferation with a portion of daughter cells replenishing the original pool and the remaining differentiating into myoblasts. These newly generated myoblasts fuse with existing muscle fibers to increase the muscle fiber size, as well as the number of nuclei in muscle fibers. Indeed, the majority of nuclei in an adult muscle fiber come from satellite cells [26]. However, recent studies indicate that a portion of satellite cells are also capable of differentiation into other cell types in addition to muscle cells, such as adipocytes and fibroblasts [27]. Physiological factors 
and mechanisms controlling the differentiation of those multipotent cells are a current research focus.

\section{Adipocyte and connective tissue development}

In addition to energy storage, adipose tissue is a very important organ for secretion of many endocrine and paracrine factors [28-33]. Adipose tissue plays a critical role in the regulation of whole body metabolism and homeostasis [28, 34]. At the molecular level, the development of adipose tissue relies on preadipocyte hyperplasia, switching from proliferation to lipid assimilation, adipocyte hypertrophy and angiogenesis. Adipogenesis is the de novo development of adipocytes. Similar to myogenesis, however, adipogenesis can be briefly divided into two steps: determination and differentiation.

Key transcription factors regulating adipogenesis include the peroxisome proliferator-activated receptor (PPAR) $\gamma$ and CCAAT/enhancer-binding proteins (C/EBPs) [31]. PPARY is highly expressed and plays an indispensible role in the differentiation of adipocytes [35]. C/EBP $\beta / \delta$, which are induced in the early phases of adipogenesis, trigger the expression of PPARY [36]. Bone morphogenetic proteins (BMPs), which belong to the transforming growth factors $\beta$ (TGF $\beta$ ) superfamily, exert important roles in the adipogenic determination from multipotent stem cells [37]. The Wnt signaling pathway inhibits adipogenesis [38].

Fibrogenesis refers to the formation of connective tissue. Fibrosis is characterized by the enhanced deposition of extracellular matrix (ECM) proteins in basement membrane and interstitial tissue of muscle [39]. A number of cytokines and growth factors are associated with the development of fibrosis, among which TGF $\beta$ has been recognized as the most powerful and widely expressed profibrogenic cytokine [39]. There are currently three TGF $\beta$ isoforms identified, including TGF $\beta 1$, TGF $\beta 2$ and TGF $\beta 3$; TGF $\beta 1$ is mainly expressed in endothelial cells, fibroblasts, hematopoietic cells and smooth muscle cells, TGF $\beta 2$ is primarily expressed in epithelial cells and neurons, and TGF $\beta 3$ is specifically expressed in mesenchymal cells [40]. However, the three isoforms of TGF $\beta$ transduce the signals through the same serine-threonine kinase cell surface receptors, including type I and type II receptors [41, 42]. Activation of TGF $\beta$ receptors induces the Smad signaling pathway [43] and the expression of target genes possessing Smad-specific elements in their promoters [44], leading to the synthesis of collagens $[45,46]$ and accumulation of extracellular matrix [47].

\section{Myogenesis, adipogenesis and fibrogenesis are competitive processes}

Fetal and neonatal skeletal muscle development occur in the same microenvironment and involve myogenesis, adipogenesis and fibrogenesis [19], all of which are derived mainly from mesenchymal stem cells. Therefore, the commitment of mesenchymal stem cells to myogenic, adipogenic or fibrogenic lineages can be considered a competitive process, and is "shaped" by numerous inductive regulators. Switching the commitment of stem cells from myogenesis to adipogenesis will increase intramuscular fat, an event associated with skeletal muscle insulin resistance due to the paracrine effect of intramuscular adipocytes [48-50], and switching to fibrogenesis leads to impairment of muscle function including oxidative capacity [51]. In addition, attenuation of myogenesis will reduce the muscle fiber density [22], exerting permanent negative effect on offspring muscle strength [52]. During aging, a progressive loss of muscle mass occurs accompanied by increased adiposity and fibrosis $[51,53]$, resulting in the decline in muscle structural integrity and functional capacity [54]. Thus, proper differentiation of mesenchymal stem cells during fetal development is crucial for the long-term health of offspring.

\section{Maternal Nutrition and Fetal Programming Fetal programming}

Fetal programming, also known as developmental programming or the Barker hypothesis, pertains to the fetal origins of adult diseases. This hypothesis is based on epidemiological data that show that low birth weight due to maternal malnutrition has long-term effects on adult health [55]. The fetal programming hypothesis suggests that the alteration in the uterine environment as a result of nutritional stress at certain stages of conceptus growth and development might permanently change tissue structure and function [56]. The offspring of malnourished mothers have a higher chance of developing coronary heart diseases, stroke, diabetes and hypertension [57]. The prevalence of type-II diabetes (T2D) increases 3 fold for men who weighed $5.5 \mathrm{lb}$ at birth when compared to those who had birth weight of $9.5 \mathrm{lb}$ [58]. The correlation between human maternal nutrition and offspring birth weight and the subsequent development of hypertension, insulin resistance, T2D and cardiovascular diseases has been well studied by many researchers $[8,21,23,59-64]$. 


\section{Maternal undernutrition of skeletal muscle de- velopment}

Maternal nutrition affects fetal development, especially fetal skeletal muscle development [7]. Maternal nutrition during the embryonic stage has relatively minor effects on skeletal muscle development, because only a very small number of myofibers are formed during this stage. Beef cattle receiving 30\% nutrient restriction during 30 to $120 \mathrm{~d}$ of gestation had no effect on fetal body weight and carcass weight [65]. In a sheep study, 50\% nutrient restriction from 18 days before until $6 \mathrm{~d}$ after conception decreased the number of muscle fibers, though fetal body weight at mid-gestation was not affected [66].

The critical stage for fetal skeletal muscle development is early to mid-gestation in the cattle and sheep, and mid to late gestation in pigs. A $50 \%$ decrease of nutrient availability in sheep from d 28 to 78 of gestation reduced the formation of secondary myofibers, and the ratio of secondary to primary myofibers [7]. It is also known that reducing skeletal muscle mass during fetal development have long-lasting, irreversible negative physiological consequences for offspring $[67,68]$. So it is not surprising that the $8 \mathrm{~m}$ old offspring lambs born to nutrient-restricted mothers have fewer muscle fibers than control lambs [8]. Similar results were also observed in new born pigs [69], as well as in guinea pigs [70] with in-utero under-nutrition.

For the late gestation stage, maternal nutrient restriction does not have major impacts on the number of muscle fibers in cattle and sheep because skeletal muscle has matured [18]. Skeletal muscle matures in about d 105 of gestation in sheep (term about $150 \mathrm{~d}$ ) and $\mathrm{d} 210$ of gestation in cattle (term about $285 \mathrm{~d}$ ) [18]. Maternal restriction at this time, however, does reduce muscle fiber size [71]. These results were also confirmed in a sheep study, when the growth of skeletal muscle was compared in single with twin pregnancies, only the hypertrophy but not the hyperplasia of skeletal muscle was affected [72]. In summary, maternal under-nutrition during early to mid-gestation reduces muscle fiber numbers and during late-gestation decreases muscle fiber sizes in sheep and cattle; in rodents and pigs, the mid to late gestation are important for muscle fiber formation.

\section{Maternal over-nutrition and fetal skeletal muscle development}

Besides maternal nutrient deficiency, maternal over-nutrition also affects fetal skeletal muscle development, mainly enhancing intramuscular adipogenesis and fibrogenesis. In ruminant animals and humans, adipogenesis begins around mid-gestation, which overlaps with myogenesis $[18,19,30]$. During fetal skeletal muscle development, a small portion of the progenitor cells differentiate into adipocytes, which form intramuscular fat and marbling in offspring [22]. Enhanced intramuscular fat accumulation is detrimental for health because increased intramuscular fat leads to skeletal muscle insulin resistance due to the paracrine effect of intramuscular adipocytes [48-50], pre-disposing to Type 2 diabetes. However, in animal production, enhancement of intramuscular fat accumulation or marbling improves meat quality; the amount of marbling is crucial for the flavor and juiciness of meat [73], and is determined by the number and size of intramuscular adipocytes [18]. Maternal over-nutrition elevates the expression of adipogenesis markers in skeletal muscle of mid-gestation fetuses [27]. A subsequent study also demonstrated that maternal over-nutrition resulted in increased number and size of adipocytes inside skeletal muscle of fetal sheep at late-gestation [23]. Postnatally, the increased adipocytes and total triglyceride content were also observed in offspring sheep of over-nourished mothers [4].

Besides myofibers and adipocytes, mesodermal progenitor cells can also differentiate into fibroblasts. These cells synthesize connective tissue which forms endomysium, perimysium and epimysium in fetal skeletal muscle during late gestation [19]. Maternal over-nutrition increases the collagen content and cross-linking of skeletal muscle, heart and large intestine of fetuses, suggesting an important role of maternal nutrition during pregnancy in fetal fibrogenesis [74-76]. Similar increase in collagen and cross-linking was also observed in skeletal muscle of offspring with maternal over-nutrition [4].

In summary, maternal over-nutrition enhances intramuscular adipogenesis and fibrogenesis, increasing intramuscular fat and connective tissue content in offspring muscle.

\section{Mechanisms Associated with Fetal Pro- gramming of Skeletal Muscle and Adipose Tissue Development MicroRNAs}

MicroRNAs (miRNAs) introduction: MiRNAs are single-strand RNA molecules of 21-23 nucleotides in length [77], which play a crucial role in developmental processes by regulating the expression of target mRNA [78]. The target mRNA transcripts of miRNAs include genes which play important roles in proliferation and differentiation [79]. So far, thousands of miRNAs have been discovered; thus, miRNAs have become one of the most abundant categories of gene 
regulatory molecules in multicellular organisms [80]. It is estimated that about $30 \%$ of all protein-coding genes are regulated by miRNAs [81].

MiRNA and skeletal muscle development: In 2006, miR-206 was the first miRNA shown to play an important role in skeletal muscle development by regulating the expression of connexin43, a gap junction protein required for skeletal myoblast fusion [82]. MiR-206, as well as miR-1 and miR-133, are muscle specific miRNAs [83-85]. MyoD induces the transcription of miR-206 [86], which promotes myogenic differentiation [87, 88]. BMP-2, which is known to inhibit myogenesis, represses the expression of miR-206 by inhibiting its maturation process [89]. Besides miR-206, miR-1 also promotes myogenic differentiation [90]. Overexpression of miR-1 increases the expression of a-actin, sarcomeric myosin and creatine kinase [90]. MicroR-181, a miRNA up-regulated during muscle differentiation, is likewise very important in muscle development [91]. MiR-133 induces myoblast proliferation [92]. MEF2 transcription factor, a critical regulator of myogenesis, induces the expression of miR-1 and miR-133 [93]. MiR-133 also regulates connective tissue growth factor, a key mediator of fibrosis [94]. MiR-1 and miR-133 in zebrafish control the expression of muscle genes and regulate sarcomeric actin organization [95]. The expression of miR-133 increases during myogenic differentiation of C2C12 cells, as visualized by a GFP-related retroviral vector system [96]. In addition, miR-181 promotes myogenesis by down-regulating the homeobox protein Hox-A11, an inhibitor of muscle differentiation [91]. MiR-27b regulates Pax3 protein level and ensures myogenic differentiation [97]. MiR-322/424 and miR-503 are induced during muscle differentiation and arrest the cell cycle by down-regulating Cdc25A [98]. MiR-486 has also been shown to induce myoblast differentiation by down-regulating Pax7 [99]. Repression of miR-214 expression inhibits proliferation and differentiation of C2C12 cells [100]. Fibroblast growth factors, which inhibit myogenic differentiation of C2C12 cells and interfere with the activity of MRFs, repress the expression of miR-206, miR-1 and miR-133 [101].

MiRNA and adipocyte differentiation: MiRNAs are involved in the regulation of adipogenesis. In 2004, miR-143 was determined to promote adipocyte differentiation [102]. Then, an in vitro study reported that 21 of the 100 miRNAs were differentially expressed before and after differentiation of 3T3-L1 preadipocytes [103]. Another study also demonstrated that miR-17-92 promotes adipogenic differentiation [104]. Moreover, miR-200 family promotes adipogenesis by inhibiting the Wnt signaling which is a negative reg- ulator of adipogenesis [105]. Later studies also showed the role of miR-27 and let-7 in the regulation of adipogenesis $[106,107]$. Over-expression of miR-27 prior to induction of adipogenesis inhibited adipogenesis by prevention of the expression of PPARY and C/EBPa [106]. A recent study also demonstrated that miR-130 represses adipogenesis by inhibiting the expression of PPARY [108].

MiRNA and stem cell proliferation and differentiation: MiRNAs are likely candidates for the maintenance of stem cell identity, which includes self-renewal and cell destiny decision, because miRNAs have the ability to control the expression of many targets simultaneously and provide a means for coordinated regulation of gene action [109]. The first study about miRNAs in stem cells reported several embryonic stem cell-specific miRNAs [110]. Subsequently, a number of studies indicated that miRNA are key regulators in stem cell functions [111].

MiRNAs are essential regulators of stem cell self-renewal and proliferation [109]. There are miRNAs only expressed in pluripotent embryonic stem (ES) cells but not in adult cells, which might play roles in stem cell self-renewal [112]. Stem cell division in Drosophila is regulated by a miRNA pathway, and germline stem cells with a mutation in Dicer1 are normal in identity but defective in cell cycle control [113]. Other studies have also shown that Dicer $1 \mathrm{mu}-$ tation leads to developmental arrest in zebrafish [114], embryonic lethality in mouse [115] and lower proliferation of ES cells [116]. The expression of miRNAs differs in undifferentiated and differentiated ES cells $[117,118]$, as well as in multipotent mesenchymal stromal cells $[119,120]$, indicating the involvement of miRNA in the regulation of stem cell phenotypes.

\section{Epigenetics and its possible roles in fetal pro- gramming of skeletal muscle development}

Epigenetics describes heritable changes in gene function without changes in gene sequence [121]. Epigenetic changes can pass from one cell generation to the next (mitotic inheritance), as well as from one generation of a species to the next (meiotic inheritance) [122]. Epigenetic modifications include DNA methylation, histone modification and microRNAs, which explain cell differentiation into different cell types with various phenotypes despite the same DNA sequence [122]. Interestingly, epigenetic status can be influenced by environmental factors [123], suggesting that pathogenic physiological conditions, such as low-grade inflammation associated with obesity, may induce epigenetic modifications and thus alter cell differentiation and lineage commitments.

DNA methylation: DNA methylation occurs on 
cytosine residues of CG dinucleotides (also called CpG sites), which normally results in transcriptional silencing [124]. A typical example of DNA methylation could be the inactivation of one of the $\mathrm{X}$ chromosomes in female genome [125]. DNA methylation silences genes through several mechanisms: 1) recruitment of histone deacetylases, which removes histone acetylations inhibiting gene expression; 2) DNA methylation can interfere the binding of transcription factors; and 3) DNA methylation leads to formation of inactive chromatin structures [126].

DNA methylation is regulated by the DNA cytosine methyltransferases (DNMT), which include DNMT1, DNMT3a and DNMT3b in vertebrates [127]. DNMT1 is the maintenance DNA methytransferase, which functions on hemimethylated DNA during mitosis [128]. DNMT3 is also called the de novo methyltransferase, which works on unmodified DNA and has very important roles in cell differentiation and commitment during embryogenesis [129].

Histone modifications: In eukaryotic cells, genomic DNA binds with histones, together called chromatin. There are four core histones (H2A, H2B, H3, H4), usually densely packed, with their N-terminal tails unstructured and could be modified by enzymes, leading to acetylation, methylation, phosphorytion, sumoylation, ubiquitylation and other modifications [130]. DNA methylation could further recruit histone deacetyltransfereases (HDACs), which lead to histone deacetylation and chromatin condensation [131].

Polycomb group proteins (PcG) and trithorax $(\operatorname{trx} G)$ group proteins regulate histone methylation, which leads to other epigenetic modifications during cell differentiation [132]. PcG and trxG regulate the methylation of histone $\mathrm{H} 3$ through binding to $\mathrm{PcG}$ and trxG genomic response elements. PcG group proteins possesses H3K27-specific trimethylase activity which mediates gene expression repression, whereas trxG complexes have H3K4 trimethylase activity which mediates activation [133]. The PcG protein EZH2 (enhancer of Zeste homolog 2) serves as a recruitment platform for DNMTs, thus converting plastic histone modifications to stable DNA methylations [134]. Cell differentiation is associated with histone modifications and DNA methylations. Currently, there are no data available linking maternal nutrition to PcG and trxG protein functions during fetal muscle and adipose tissue development but inflammation, a condition associated with obesity, leads to alterations in PcG protein groups [135]. Because maternal obesity leads to inflammation in fetal muscle [23], this indirect evidence supports the role of epigenetic modification in developmental programming of skeletal muscle in offspring, which needs to be confirmed. Epigenetic changes in fetal muscle and adipose tissue due to maternal nutrition and other physiological conditions should be the focus for future research.

\section{Summary}

The embryo-fetal stage is crucial for skeletal muscle development, as well as for adipose and connective tissue development. Maternal nutrition affects the proliferation of myogenic precursor cells and, thus, the subsequent number of muscle fibers formed. Alternatively, maternal over-nutrition during mid-gestation results in impaired myogenesis and elevated adipogenesis. The underlying mechanisms for the changes observed in fetal skeletal muscle in the setting of maternal obesity remain largely unknown. In addition to alteration of inductive regulators, it is likely that miRNA may be involved in the regulation of myogenesis and adipogenesis during fetal muscle development, which warrants further studies. In addition, epigenetic changes such as DNA methylation are expected to alter cell lineage commitment during fetal muscle and adipose tissue development, a question not yet examined in the framework of developmental programming of skeletal muscle.

\section{Conflict of Interest}

The authors have declared that no conflict of interest exists.

\section{References}

1. Flegal KM, Carroll MD, Ogden CL, Curtin LR. Prevalence and trends in obesity among US adults, 1999-2008. JAMA 2010303 : 235-241.

2. Ogden CL, Carroll MD, Curtin LR, Lamb MM, Flegal KM. Prevalence of high body mass index in US children and adolescents, 2007-2008. JAMA 2010 303: 242-249.

3. King JC. Maternal obesity, metabolism, and pregnancy outcomes. Annu Rev Nutr 2006 26: 271-291.

4. Yan X, Huang Y, Zhao JX, Long NM, Uthlaut AB, Zhu MJ, Ford SP, Nathanielsz PW, Du M. Maternal obesity-impaired insulin signaling in sheep and induced lipid accumulation and fibrosis in skeletal muscle of offspring. Biol Reprod 2011 85: 172-178.

5. Nathanielsz PW. Animal models that elucidate basic principles of the developmental origins of adult diseases. Ilar J 2006 47: 73-82.

6. Barker DJ. Fetal programming of coronary heart disease. Trends Endocrinol Metab 2002 13: 364-368.

7. Zhu MJ, Ford SP, Nathanielsz PW, Du M. Effect of maternal nutrient restriction in sheep on the development of fetal skeletal muscle. Biol Reprod 2004 71: 1968-1973.

8. Zhu MJ, Ford SP, Means WJ, Hess BW, Nathanielsz PW, Du M. Maternal nutrient restriction affects properties of skeletal muscle in offspring. J Physiol 2006 575: 241-250.

9. Sciote JJ, Morris TJ. Skeletal muscle function and fibre types: the relationship between occlusal function and the phenotype of jaw-closing muscles in human. J Orthod 2000 27: 15-30.

10. Bailey P, Holowacz T, Lassar AB. The origin of skeletal muscle stem cells in the embryo and the adult. Curr Opin Cell Biol 2001 13: 679-689. 
11. Hyatt JP, McCall GE, Kander EM, Zhong H, Roy RR, Huey KA. PAX3/7 expression coincides with myod during chronic skeletal muscle overload. Muscle Nerve 2008 38: 861-866.

12. Maroto M, Reshef R, Munsterberg AE, Koester S, Goulding M, Lassar AB. Ectopic Pax-3 activates MyoD and Myf-5 expression in embryonic mesoderm and neural tissue. Cell 1997 89: 139-148.

13. Cossu G, Borello U. Wnt signaling and the activation of myogenesis in mammals. EMBO J 1999 18: 6867-6872.

14. Amthor H, Christ B, Patel K. A molecular mechanism enabling continuous embryonic muscle growth - a balance between proliferation and differentiation. Development 1999 126: 1041-1053.

15. Stewart CE, Rittweger J. Adaptive processes in skeletal muscle: molecular regulators and genetic influences. J Musculoskelet Neuronal Interact 2006 6: 73-86.

16. Barnoy S, Kosower NS. Calpastatin in rat myoblasts: transient diminution and decreased phosphorylation depend on myogenin-directed myoblast differentiation. Int J Biochem Cell Biol 2007 39: 253-261.

17. Roth JF, Shikama N, Henzen C, Desbaillets I, Lutz W, Marino S, Wittwer J, Schorle H, Gassmann M, Eckner R. Differential role of p300 and CBP acetyltransferase during myogenesis: p300 acts upstream of MyoD and Myf5. EMBO J 2003 22: 5186-5196.

18. Du M, Tong J, Zhao J, Underwood KR, Zhu M, Ford SP, Nathanielsz PW. Fetal programming of skeletal muscle development in ruminant animals. J Anim Sci 2010 88: E51-60.

19. Du M, Yan X, Tong JF, Zhao J, Zhu MJ. Maternal obesity, inflammation, and fetal skeletal muscle development. Biol Reprod 2010 82: 4-12.

20. Greenwood PL, Hunt AS, Hermanson JW, Bell AW. Effects of birth weight and postnatal nutrition on neonatal sheep: II. Skeletal muscle growth and development. J Anim Sci 2000 78: 50-61.

21. Zhu MJ, Han B, Tong J, Ma C, Kimzey JM, Underwood KR, Xiao Y, Hess BW, Ford SP, Nathanielsz PW, Du M. AMP-activated protein kinase signalling pathways are down regulated and skeletal muscle development impaired in fetuses of obese, over-nourished sheep. J Physiol 2008 586: 2651-2664.

22. Tong JF, Yan X, Zhu MJ, Ford SP, Nathanielsz PW, Du M. Maternal obesity downregulates myogenesis and beta-catenin signaling in fetal skeletal muscle. Am J Physiol Endocrinol Metab 2009 296: E917-924.

23. Yan X, Zhu MJ, Xu W, Tong JF, Ford SP, Nathanielsz PW, Du M. Up-regulation of Toll-like receptor 4/nuclear factor-kappaB signaling is associated with enhanced adipogenesis and insulin resistance in fetal skeletal muscle of obese sheep at late gestation. Endocrinology 2010 151: 380-387.

24. Brameld JM, Mostyn A, Dandrea J, Stephenson TJ, Dawson JM, Buttery PJ, Symonds ME. Maternal nutrition alters the expression of insulin-like growth factors in fetal sheep liver and skeletal muscle. J Endocrinol 2000 167: 429-437.

25. Shefer G, Yablonka-Reuveni Z. Reflections on lineage potential of skeletal muscle satellite cells: do they sometimes go MAD? Crit Rev Eukaryot Gene Expr 2007 17: 13-29.

26. Allen RE, Merkel RA, Young RB. Cellular aspects of muscle growth: myogenic cell proliferation. J Anim Sci 1979 49: 115-127.

27. Tong J, Zhu MJ, Underwood KR, Hess BW, Ford SP, Du M. AMP-activated protein kinase and adipogenesis in sheep fetal skeletal muscle and 3T3-L1 cells. J Anim Sci 2008 86: 1296-1305.

28. Ailhaud G. Adipose tissue as a secretory organ: from adipogenesis to the metabolic syndrome. C R Biol 2006 329: 570-577.

29. Camp HS, Ren D, Leff T. Adipogenesis and fat-cell function in obesity and diabetes. Trends Mol Med 2002 8: 442-447.
30. Feve B. Adipogenesis: cellular and molecular aspects. Best Pract Res Clin Endocrinol Metab 2005 19: 483-499.

31. Avram MM, Avram AS, James WD. Subcutaneous fat in normal and diseased states 3. Adipogenesis: from stem cell to fat cell. J Am Acad Dermatol 2007 56: 472-492.

32. Alessi MC, Peiretti F, Morange P, Henry M, Nalbone G, Juhan-Vague I. Production of plasminogen activator inhibitor 1 by human adipose tissue: possible link between visceral fat accumulation and vascular disease. Diabetes 1997 46: 860-867.

33. Lundgren $\mathrm{CH}$, Brown SL, Nordt TK, Sobel BE, Fujii S. Elaboration of type-1 plasminogen activator inhibitor from adipocytes. A potential pathogenetic link between obesity and cardiovascular disease. Circulation 1996 93: 106-110.

34. Kahn BB, Flier JS. Obesity and insulin resistance. J Clin Invest 2000 106: 473-481.

35. Morrison RF, Farmer SR. Hormonal signaling and transcriptional control of adipocyte differentiation. J Nutr 2000 130: 3116S-3121S.

36. Fajas L, Debril MB, Auwerx J. Peroxisome proliferator-activated receptor-gamma: from adipogenesis to carcinogenesis. J Mol Endocrinol 2001 27: 1-9.

37. MacDougald OA, Mandrup S. Adipogenesis: forces that tip the scales. Trends Endocrinol Metab 2002 13: 5-11.

38. Rosen ED, MacDougald OA. Adipocyte differentiation from the inside out. Nat Rev Mol Cell Biol 2006 7: 885-896.

39. Liu RM, Gaston Pravia KA. Oxidative stress and glutathione in TGF-beta-mediated fibrogenesis. Free Radic Biol Med 2010 48: $1-15$.

40. Ghosh J, Murphy MO, Turner N, Khwaja N, Halka A, Kielty CM, Walker MG. The role of transforming growth factor beta1 in the vascular system. Cardiovasc Pathol 2005 14: 28-36.

41. Attisano L, Wrana JL. Signal transduction by members of the transforming growth factor-beta superfamily. Cytokine Growth Factor Rev 1996 7: 327-339.

42. Letterio JJ, Roberts AB. Regulation of immune responses by TGF-beta. Annu Rev Immunol 1998 16: 137-161.

43. Suwanabol PA, Kent KC, Liu B. TGF-beta and restenosis revisited: a Smad link. J Surg Res 2011 167: 287-297.

44. Massague J, Chen YG. Controlling TGF-beta signaling. Genes Dev 2000 14: 627-644.

45. Inagaki $Y$, Truter S, Ramirez F. Transforming growth factor-beta stimulates alpha 2(I) collagen gene expression through a cis-acting element that contains an Sp1-binding site. J Biol Chem 1994 269: 14828-14834.

46. Tsukada S, Westwick JK, Ikejima K, Sato N, Rippe RA. SMAD and p38 MAPK signaling pathways independently regulate alpha1(I) collagen gene expression in unstimulated and transforming growth factor-beta-stimulated hepatic stellate cells. J Biol Chem 2005 280: 10055-10064.

47. Roberts AB, Heine UI, Flanders KC, Sporn MB. Transforming growth factor-beta. Major role in regulation of extracellular matrix. Ann N Y Acad Sci 1990 580: 225-232.

48. Petersen KF, Shulman GI. Pathogenesis of skeletal muscle insulin resistance in type 2 diabetes mellitus. Am J Cardiol 2002 90: 11G-18G.

49. Kim JK, Michael MD, Previs SF, Peroni OD, Mauvais-Jarvis F, Neschen S, Kahn BB, Kahn CR, Shulman GI. Redistribution of substrates to adipose tissue promotes obesity in mice with selective insulin resistance in muscle. J Clin Invest 2000 105: 1791-1797.

50. Aguiari P, Leo S, Zavan B, Vindigni V, Rimessi A, Bianchi K, Franzin C, Cortivo R, Rossato M, Vettor R, Abatangelo G, Pozzan T, et al. High glucose induces adipogenic differentiation of muscle-derived stem cells. Proc Natl Acad Sci U S A 2008 105: 1226-1231.

51. Lahoute C, Sotiropoulos A, Favier M, Guillet-Deniau I, Charvet C, Ferry A, Butler-Browne G, Metzger D, Tuil D, Daegelen D. 
Premature aging in skeletal muscle lacking serum response factor. PLoS ONE 2008 3: e3910.

52. Bayol SA, Macharia R, Farrington SJ, Simbi BH, Stickland NC. Evidence that a maternal "junk food" diet during pregnancy and lactation can reduce muscle force in offspring. Eur J Nutr 2009 48: 62-65.

53. Brack AS, Conboy MJ, Roy S, Lee M, Kuo CJ, Keller C, Rando TA. Increased Wnt signaling during aging alters muscle stem cell fate and increases fibrosis. Science 2007 317: 807-810.

54. Beggs ML, Nagarajan R, Taylor-Jones JM, Nolen G, Macnicol M, Peterson CA. Alterations in the TGFbeta signaling pathway in myogenic progenitors with age. Aging Cell 2004 3: 353-361.

55. Barker DJ, Eriksson JG, Forsen T, Osmond C. Fetal origins of adult disease: strength of effects and biological basis. Int J Epidemiol 2002 31: 1235-1239.

56. Drake AJ, Walker BR. The intergenerational effects of fetal programming: non-genomic mechanisms for the inheritance of low birth weight and cardiovascular risk. J Endocrinol 2004 180: 1-16.

57. Barker DJ. Coronary heart disease: a disorder of growth. Horm Res 200359 Suppl 1: 35-41.

58. Hales CN, Barker DJ, Clark PM, Cox LJ, Fall C, Osmond C, Winter PD. Fetal and infant growth and impaired glucose tolerance at age 64. BMJ 1991 303: 1019-1022.

59. Barker DJ, Osmond C. Low birth weight and hypertension. BMJ 1988 297: 134-135.

60. Bavdekar A, Yajnik CS, Fall CH, Bapat S, Pandit AN, Deshpande V, Bhave S, Kellingray SD, Joglekar C. Insulin resistance syndrome in 8-year-old Indian children: small at birth, big at 8 years, or both? Diabetes 1999 48: 2422-2429.

61. Eriksson JG, Forsen T, Tuomilehto J, Winter PD, Osmond C, Barker DJ. Catch-up growth in childhood and death from coronary heart disease: longitudinal study. BMJ 1999 318: 427-431.

62. Mathews F, Yudkin P, Neil A. Influence of maternal nutrition on outcome of pregnancy: prospective cohort study. BMJ 1999 319: 339-343.

63. Ford SP, Hess BW, Schwope MM, Nijland MJ, Gilbert JS, Vonnahme KA, Means WJ, Han H, Nathanielsz PW. Maternal undernutrition during early to mid-gestation in the ewe results in altered growth, adiposity, and glucose tolerance in male offspring. J Anim Sci 2007 85: 1285-1294.

64. Yan X, Huang Y, Zhao JX, Long NM, Uthlaut AB, Zhu MJ, Ford SP, Nathanielsz PW, Du M. Maternal Obesity-Impaired Insulin Signaling in Sheep and Induced Lipid Accumulation and Fibrosis in Skeletal Muscle of Offspring. Biol Reprod 2011 85: 172-178.

65. Du M, Zhu MJ, Means WJ, Hess BW, Ford SP. Nutrient restriction differentially modulates the mammalian target of rapamycin signaling and the ubiquitin-proteasome system in skeletal muscle of cows and their fetuses. J Anim Sci 2005 83: 117-123.

66. Quigley SP, Kleemann DO, Kakar MA, Owens JA, Nattrass GS, Maddocks S, Walker SK. Myogenesis in sheep is altered by maternal feed intake during the peri-conception period. Anim Reprod Sci 2005 87: 241-251.

67. Stannard SR, Johnson NA. Insulin resistance and elevated triglyceride in muscle: more important for survival than "thrifty" genes? J Physiol 2004 554: 595-607.

68. Zambrano E, Rodriguez-Gonzalez GL, Guzman C, Garcia-Becerra R, Boeck L, Diaz L, Menjivar M, Larrea F, Nathanielsz PW. A maternal low protein diet during pregnancy and lactation in the rat impairs male reproductive development. J Physiol 2005 563: 275-284.

69. Dwyer CM, Stickland NC, Fletcher JM. The influence of maternal nutrition on muscle fiber number development in the porcine fetus and on subsequent postnatal growth. J Anim Sci 1994 72: 911-917.

70. Ward SS, Stickland NC. Why are slow and fast muscles differentially affected during prenatal undernutrition? Muscle Nerve 1991 14: 259-267.

71. Greenwood PL, Slepetis RM, Hermanson JW, Bell AW. Intrauterine growth retardation is associated with reduced cell cycle activity, but not myofibre number, in ovine fetal muscle. Reprod Fertil Dev 1999 11: 281-291.

72. McCoard SA, McNabb WC, Peterson SW, McCutcheon SN, Harris PM. Muscle growth, cell number, type and morphometry in single and twin fetal lambs during mid to late gestation. Reprod Fertil Dev 2000 12: 319-327.

73. Dodson MV, Hausman GJ, Guan L, Du M, Rasmussen TP, Poulos SP, Mir P, Bergen WG, Fernyhough ME, McFarland DC, Rhoads RP, Soret B, et al. Skeletal muscle stem cells from animals I. Basic cell biology. Int J Biol Sci 2010 6: 465-474.

74. Huang Y, Yan X, Zhao JX, Zhu MJ, McCormick RJ, Ford SP, Nathanielsz PW, Ren J, Du M. Maternal obesity induces fibrosis in fetal myocardium of sheep. Am J Physiol Endocrinol Metab 2010 299: E968-975.

75. Huang Y, Yan X, Zhu MJ, McCormick RJ, Ford SP, Nathanielsz PW, Du M. Enhanced transforming growth factor-beta signaling and fibrogenesis in ovine fetal skeletal muscle of obese dams at late gestation. Am J Physiol Endocrinol Metab 2010 298: E1254-1260.

76. Yan X, Huang Y, Wang $H$, Du M, Hess BW, Ford SP, Nathanielsz PW, Zhu MJ. Maternal obesity induces sustained inflammation in both fetal and offspring large intestine of sheep. Inflamm Bowel Dis 2011 17: 1513-1522.

77. Jin W, Dodson MV, Moore SS, Basarab JA, Guan LL. Characterization of microRNA expression in bovine adipose tissues: a potential regulatory mechanism of subcutaneous adipose tissue development. BMC Mol Biol 2010 11: 29.

78. Bartel DP. MicroRNAs: genomics, biogenesis, mechanism, and function. Cell 2004 116: 281-297.

79. Kumar MS, Lu J, Mercer KL, Golub TR, Jacks T. Impaired microRNA processing enhances cellular transformation and tumorigenesis. Nat Genet 2007 39: 673-677.

80. Guay C, Roggli E, Nesca V, Jacovetti C, Regazzi R. Diabetes mellitus, a microRNA-related disease? Transl Res 2011 157: 253-264.

81. Lewis BP, Shih IH, Jones-Rhoades MW, Bartel DP, Burge CB. Prediction of mammalian microRNA targets. Cell 2003 115: 787-798.

82. Anderson C, Catoe H, Werner R. MIR-206 regulates connexin43 expression during skeletal muscle development. Nucleic Acids Res 2006 34: 5863-5871.

83. Kim HK, Lee YS, Sivaprasad U, Malhotra A, Dutta A. Muscle-specific microRNA miR-206 promotes muscle differentiation. J Cell Biol 2006 174: 677-687.

84. Rao PK, Kumar RM, Farkhondeh M, Baskerville S, Lodish HF. Myogenic factors that regulate expression of muscle-specific microRNAs. Proc Natl Acad Sci U S A 2006 103: 8721-8726.

85. McCarthy JJ. MicroRNA-206: the skeletal muscle-specific myomiR. Biochim Biophys Acta 2008 1779: 682-691.

86. Rosenberg MI, Georges SA, Asawachaicharn A, Analau E, Tapscott SJ. MyoD inhibits Fstl1 and Utrn expression by inducing transcription of miR-206. J Cell Biol 2006 175: 77-85.

87. Taulli R, Bersani F, Foglizzo V, Linari A, Vigna E, Ladanyi M, Tuschl T, Ponzetto C. The muscle-specific microRNA miR-206 blocks human rhabdomyosarcoma growth in xenotransplanted mice by promoting myogenic differentiation. J Clin Invest 2009 119: 2366-2378.

88. Missiaglia E, Shepherd CJ, Patel S, Thway K, Pierron G, Pritchard-Jones K, Renard M, Sciot R, Rao P, Oberlin O, Delattre O, Shipley J. MicroRNA-206 expression levels correlate with 
clinical behaviour of rhabdomyosarcomas. Br J Cancer 2010 102: 1769-1777.

89. Sato MM, Nashimoto M, Katagiri T, Yawaka Y, Tamura M. Bone morphogenetic protein-2 down-regulates miR-206 expression by blocking its maturation process. Biochem Biophys Res Commun 2009 383: 125-129.

90. Nakajima N, Takahashi T, Kitamura R, Isodono K, Asada S, Ueyama T, Matsubara H, Oh H. MicroRNA-1 facilitates skeletal myogenic differentiation without affecting osteoblastic and adipogenic differentiation. Biochem Biophys Res Commun 2006 350: 1006-1012.

91. Naguibneva I, Polesskaya A, Ameyar-Zazoua M, Souidi M, Groisman R, Cuvellier S, Ait-Si-Ali S, Pritchard LL, Harel-Bellan A. Micro-RNAs and muscle differentiation. J Soc Biol 2007 201: 367-376.

92. Chen JF, Mandel EM, Thomson JM, Wu Q, Callis TE, Hammond SM, Conlon FL, Wang DZ. The role of microRNA-1 and microRNA-133 in skeletal muscle proliferation and differentiation. Nat Genet 2006 38: 228-233.

93. Liu N, Williams AH, Kim Y, McAnally J, Bezprozvannaya S, Sutherland LB, Richardson JA, Bassel-Duby R, Olson EN. An intragenic MEF2-dependent enhancer directs muscle-specific expression of microRNAs 1 and 133. Proc Natl Acad Sci U S A 2007 104: 20844-20849.

94. Duisters RF, Tijsen AJ, Schroen B, Leenders JJ, Lentink V, van der Made I, Herias V, van Leeuwen RE, Schellings MW, Barenbrug P, Maessen JG, Heymans S, et al. miR-133 and miR-30 regulate connective tissue growth factor: implications for a role of microRNAs in myocardial matrix remodeling. Circ Res 2009 104: 170-178.

95. Mishima Y, Abreu-Goodger C, Staton AA, Stahlhut C, Shou C, Cheng C, Gerstein M, Enright AJ, Giraldez AJ. Zebrafish miR-1 and miR-133 shape muscle gene expression and regulate sarcomeric actin organization. Genes Dev 2009 23: 619-632.

96. Kato Y, Miyaki S, Yokoyama S, Omori S, Inoue A, Horiuchi M, Asahara H. Real-time functional imaging for monitoring miR-133 during myogenic differentiation. Int J Biochem Cell Biol 2009 41: 2225-2231.

97. Crist CG, Montarras D, Pallafacchina G, Rocancourt D, Cumano A, Conway SJ, Buckingham M. Muscle stem cell behavior is modified by microRNA-27 regulation of Pax3 expression. Proc Natl Acad Sci U S A 2009 106: 13383-13387.

98. Sarkar S, Dey BK, Dutta A. MiR-322/424 and -503 are induced during muscle differentiation and promote cell cycle quiescence and differentiation by down-regulation of Cdc25A. Mol Biol Cell 2010 21: 2138-2149.

99. Dey BK, Gagan J, Dutta A. miR-206 and -486 induce myoblast differentiation by downregulating Pax7. Mol Cell Biol 2011 31: 203-214.

100.Feng $\mathrm{Y}$, Cao JH, Li XY, Zhao SH. Inhibition of miR-214 expression represses proliferation and differentiation of $\mathrm{C} 2 \mathrm{C} 12$ myoblasts. Cell Biochem Funct 2011 29: 378-383.

101.Sweetman D, Goljanek K, Rathjen T, Oustanina S, Braun T, Dalmay T, Munsterberg A. Specific requirements of MRFs for the expression of muscle specific microRNAs, miR-1, miR-206 and miR-133. Dev Biol 2008 321: 491-499.

102.Esau C, Kang X, Peralta E, Hanson E, Marcusson EG, Ravichandran LV, Sun Y, Koo S, Perera RJ, Jain R, Dean NM, Freier SM, et al. MicroRNA-143 regulates adipocyte differentiation. J Biol Chem 2004 279: 52361-52365.

103.Kajimoto K, Naraba H, Iwai N. MicroRNA and 3T3-L1 pre-adipocyte differentiation. RNA 2006 12: 1626-1632.

104.Wang Q, Li YC, Wang J, Kong J, Qi Y, Quigg RJ, Li X. miR-17-92 cluster accelerates adipocyte differentiation by negatively regulating tumor-suppressor Rb2/p130. Proc Natl Acad Sci U S A 2008 105: 2889-2894.
105.Kennell JA, Gerin I, MacDougald OA, Cadigan KM. The microRNA miR-8 is a conserved negative regulator of Wnt signaling. Proc Natl Acad Sci U S A 2008 105: 15417-15422.

106.Lin Q, Gao Z, Alarcon RM, Ye J, Yun Z. A role of miR-27 in the regulation of adipogenesis. FEBS J 2009 276: 2348-2358.

107.Sun T, Fu M, Bookout AL, Kliewer SA, Mangelsdorf DJ. MicroRNA let-7 regulates 3T3-L1 adipogenesis. Mol Endocrinol 2009 23: 925-931.

108.Lee EK, Lee MJ, Abdelmohsen K, Kim W, Kim MM, Srikantan S, Martindale JL, Hutchison ER, Kim HH, Marasa BS, Selimyan $\mathrm{R}$, Egan JM, et al. miR-130 suppresses adipogenesis by inhibiting peroxisome proliferator-activated receptor gamma expression. Mol Cell Biol 2011 31: 626-638.

109.Chen C, Ridzon D, Lee CT, Blake J, Sun Y, Strauss WM. Defining embryonic stem cell identity using differentiation-related microRNAs and their potential targets. Mamm Genome 2007 18: 316-327.

110.Houbaviy HB, Murray MF, Sharp PA. Embryonic stem cell-specific MicroRNAs. Dev Cell 2003 5: 351-358.

111. Cheng LC, Tavazoie M, Doetsch F. Stem cells: from epigenetics to microRNAs. Neuron 2005 46: 363-367.

112.Suh MR, Lee Y, Kim JY, Kim SK, Moon SH, Lee JY, Cha KY, Chung HM, Yoon HS, Moon SY, Kim VN, Kim KS. Human embryonic stem cells express a unique set of microRNAs. Dev Biol 2004 270: 488-498.

113. Hatfield SD, Shcherbata HR, Fischer KA, Nakahara K, Carthew RW, Ruohola-Baker H. Stem cell division is regulated by the microRNA pathway. Nature 2005 435: 974-978.

114.Wienholds E, Koudijs MJ, van Eeden FJ, Cuppen E, Plasterk $\mathrm{RH}$. The microRNA-producing enzyme Dicer1 is essential for zebrafish development. Nat Genet 2003 35: 217-218.

115.Bernstein E, Kim SY, Carmell MA, Murchison EP, Alcorn H, Li MZ, Mills AA, Elledge SJ, Anderson KV, Hannon GJ. Dicer is essential for mouse development. Nat Genet 2003 35: 215-217.

116.Murchison EP, Partridge JF, Tam OH, Cheloufi S, Hannon GJ. Characterization of Dicer-deficient murine embryonic stem cells. Proc Natl Acad Sci U S A 2005 102: 12135-12140.

117.Lakshmipathy U, Love B, Goff LA, Jornsten R, Graichen R, Hart RP, Chesnut JD. MicroRNA expression pattern of undifferentiated and differentiated human embryonic stem cells. Stem Cells Dev 2007 16: 1003-1016.

118.Judson RL, Babiarz JE, Venere M, Blelloch R. Embryonic stem cell-specific microRNAs promote induced pluripotency. Nat Biotechnol 2009 27: 459-461.

119.Lakshmipathy U, Hart RP. Concise review: MicroRNA expression in multipotent mesenchymal stromal cells. Stem Cells 2008 26: 356-363.

120.Goff LA, Boucher S, Ricupero CL, Fenstermacher S, Swerdel M, Chase LG, Adams CC, Chesnut J, Lakshmipathy U, Hart RP. Differentiating human multipotent mesenchymal stromal cells regulate microRNAs: prediction of microRNA regulation by PDGF during osteogenesis. Exp Hematol 2008 36: 1354-1369.

121.Bird A. Perceptions of epigenetics. Nature 2007 447: 396-398.

122.Ling C, Groop L. Epigenetics: a molecular link between environmental factors and type 2 diabetes. Diabetes 2009 58: 2718-2725.

123.Skinner MK, Guerrero-Bosagna C. Environmental signals and transgenerational epigenetics. Epigenomics 2009 1: 111-117.

124.Singal R, Ginder GD. DNA methylation. Blood 1999 93: 4059-4070.

125.Baylin SB. Tying it all together: epigenetics, genetics, cell cycle, and cancer. Science 1997 277: 1948-1949.

126. Cameron EE, Bachman KE, Myohanen S, Herman JG, Baylin SB. Synergy of demethylation and histone deacetylase inhibition in the re-expression of genes silenced in cancer. Nat Genet 1999 21: 103-107. 
127.Zhu H, Geiman TM, Xi S, Jiang Q, Schmidtmann A, Chen T, Li $\mathrm{E}$, Muegge K. Lsh is involved in de novo methylation of DNA. EMBO J 2006 25: 335-345.

128.Leonhardt H, Page AW, Weier HU, Bestor TH. A targeting sequence directs DNA methyltransferase to sites of DNA replication in mammalian nuclei. Cell 1992 71: 865-873.

129. Okano M, Bell DW, Haber DA, Li E. DNA methyltransferases Dnmt3a and Dnmt3b are essential for de novo methylation and mammalian development. Cell 1999 99: 247-257.

130.Kouzarides T. Chromatin modifications and their function. Cell 2007 128: 693-705.

131.Bird AP, Wolffe AP. Methylation-induced repression--belts, braces, and chromatin. Cell 1999 99: 451-454.

132.Reik W. Stability and flexibility of epigenetic gene regulation in mammalian development. Nature 2007 447: 425-432.

133.Schuettengruber B, Chourrout D, Vervoort M, Leblanc B, Cavalli G. Genome regulation by polycomb and trithorax proteins. Cell 2007 128: 735-745.

134.Vire E, Brenner C, Deplus R, Blanchon L, Fraga M, Didelot C, Morey L, Van Eynde A, Bernard D, Vanderwinden JM, Bollen $\mathrm{M}$, Esteller M, et al. The Polycomb group protein EZH2 directly controls DNA methylation. Nature 2006 439: 871-874.

135.De Santa F, Totaro MG, Prosperini E, Notarbartolo S, Testa G, Natoli G. The histone H3 lysine-27 demethylase Jmjd3 links inflammation to inhibition of polycomb-mediated gene silencing. Cell 2007 130: 1083-1094. 